\title{
PENGENTASAN KEMISKINAN \\ MELALUI PENGEMBANGAN LEMBAGA DAKWAH
}

\author{
M. Syukry \\ Universitas Islam Negeri (UIN) Raden Intan Lampung \\ Jl. Letnan Kolonel H Jl. Endro Suratmin, Sukarame, Kec. Sukarame, Kota \\ Bandar Lampung, Lampung 35131 \\ Sunny1922@yahoo.co.id
}

\begin{abstract}
Proverty is a real reality that exists in every society, even this is a global prblem that afflicts all countries in the world, especially in Indonesia. In Indonesia alone poverty is a fairly complex problem and has a close relationship with various elements or elements. In a country and of course this requires a serious response by all parties, because it is not i Indonesia that based on Pancasila and UUD 45 is the realization of a just state prosperous just and evenly, so thus poverty is certainly the responsibility of all elements. Poverty reduction can bedone through three factors, namely individual obligations, obligations of others, and government obligations in carrying out obligations for policy polcies. Dakwah institutions demand responsbility to complete, or if empowering the community there must be an adequate result.
\end{abstract}

Keyword: Poverty, empowerment of dakwah institutions. 


\section{A. Pendahuluan}

Kemiskinana merupakan suatu kenyataan riil yang ada dalam setiap masyarakat, bahkan ini adala permasalahan global yang menimpa hampir semua negarayang ada di dunia ini, terutama di Indonesia. Di Indonesia sendiri kemiskinan adalah sebuah permasalahan yang cukup komplek dan memiliki keterkaitan yan erat dengan berbagai unsur atau elemen di suatu negara tersebut dan ini tentu saja membutuhkan suatu penanggulangan yag serius oleh semua pihak, karena bukankah di Indonesia ini cita-cita nasional bangsa Indonesia yang berdasarkan pancasila dan UUD 45 adalah terwujudnya suatu negara yang adil, makmur dan merata, maka dengan demikian kemiskinan sudah tentu menjadi tanggung jawab semua elemen yang ada di suatu negara, baik pemerintah, masyarakat, LSM, Lembaga-lembaga sosial, terutama lembaga keagamaan yang salah satunya adalah agama dakwah.

Salah satu lembaga keagamaan yang dapat dikatakan sebagai lembaga yang menanggulangi masalah-masalah sosial yang ada di Indonesia ini adalah lembaga-lembaga dakwah, karena dakwah dalam Islam sudah tentu hanya mengenai masalah iman dan ketaqwaan saja, akan tetapi ikut di dalamnya masalah pengentasan kemiskinan, karena biasanya kemiskinanakan ikut di dalamnya persoalan agama. Oleh karena itu uraian selanjutnya akan dibahas lebih gamblang mengenai bagaimana peran lembaga dakwah dalam pengentasan kemiskinan.

\section{B. Kemiskinan}

Pada dasarnya bila membahas masalah kemiskinan maka ini akan menemui berbagai macam kesulitan, hal ini dikarenakan dalam pembahsan sebelumnya kemiskinan itu akan terkait didalamnya berbagai macam hal, bahkan secara akademik juga para ahli dalam ilmu yang berkaitan di dalamnya mendefinisikan berbagai macam kemiskinan berbeda-bedatampak ini dilatar belakangi dengan lata belakang dan sudut pandang mereka yang berbeda-beda.

Kemiskinan dalam defenisi adalah sebagai berikut: kemiskinan yang dimaksud dalam arti ekonomi adalah "suatu keadaan yang serba kekurangan". Mungkin serba kekurangan ini bisa disfesifikasikan sebagai "ketidakmampuan untuk memperoleh kebutuhan-kebutuhan pokok" ${ }^{1} .652$

Kebutuhan-kebutuhan pokok dalam kehidupan manusia adalah kebutuhan pangan atau biasa diartikan sebagai makan dan minum sehari-hari. Bial manusia tidak dapat memenuhi kebutuhan kehidupan sehari-hari maka itu dapat disebut sebagai miskin, adapun secara

1 Nabil Subhi Ath-Thawil, Kemiskinan dan Keterbelakangan negara-negara Muslim, Mizan, Bandung, 1991, h. 36. 
ukuran penghasilan dapat menggunakan ukuran dari bank dunia adalah bila penghasilannya kurang dari 370 USSper-tahun bila di perkirakan $1 S$ $=$ RPp. 8500,- maka dapat dihitug 370US $x$ Rp. 8500= Rp. 145.000,- dan bila dibagi kedalam 12 bulan, maka penghasilannya adalah Rp. 262.100,per-bulan maka ini adalah standar penghasilan dari masyarakat miskinan.

Standar penghasilan masyarakat miskin tersebut tidak dapat dikatakan sebagai standar yang bersifat baku, hal ini dikarenakan ukuran kemiskinan itu berbeda-beda atau mengukur kemiskinan itu dapat dilakukan menurut ukuran yang umum yang berlaku pada masyarakat setempat, dalam hal ini kemiskinan dapat diklasifikasikan menurut keadaanya kepada dua yaitu: kemiskinan relatif dan kemiskinan sabjektif.

Kemiskinan relatif ialah kemiskinan yang ddasarkan kepada lingkungan sekelilingnya. Orang yang berkecukupan didaerah miskin dapat dianggap kaya, sedangkan sebaliknya orang yang berkecukupan di daerah yang kaya dapat merasa miskin. Sedangkan kemiskinan sabjektif adalah orang yang terpenuhi kebutuhan secara sabjektif, sebab tingkat kebutuhan penduduk dapat berpariasi berdasarkan pendidikan, lingkungan, adat istiadat dan sebagainya, maka tingkat kebutuhan sabjektif-pun dapat berbeda-beda. ${ }^{2}$

Dari pembahasan kemiskinan di atas, maka dapat diambil suatu kesimpulan bahwa kemiskinan adalah: suatu keadaan ketidakmampuan dalam pemenuhan kebutuhan hidup sehari-hari., yaitu kebutuhan dalam bentuk pangan atau maksimal rata-rata penghasilannya $\mathrm{Rp}$. 262.100,- perbulan.

\section{Faktor Penyebab Kemiskinan}

W. Brand menulis bahwa negara-negara yang sedang berkembang itu menjadi miskin karena:

1. Kekurangan modal

2. Taraf pendidikannya rendah

3. Kekurangan kepemimpinan untuk mendorong kemajuan ekonomi. ${ }^{3}$

Selain telah disbutkan diatas, maka faktor-faktor lain yang dapat dijadikan sebagai faktor penyebab kemiskinan yang lainnya adaah:

Kepadatan penduduk, yang setiap tahun semakin menambah, sedangkan lahan tanah otomatis semakin menyempit dan tentu saja

\footnotetext{
${ }^{2}$ Adi Sasono, Zakat Untuk Mengurangi Kemiskinan Ummat, Makalah.1995.1995, h.
}

4.

${ }^{3}$ Surjadi, Dakwah Islam dan Pembangunan Masyarakat Desa, Mandar Maju, Bandung, 1989, h. 53. 
kebutuhan pangan semakin banyak, sedangkan hal tersebut sulit tersedia.

Malthus berpendapat bahwa kesentosaan manusia senantiasa diganggu oleh kenyataan pertambahan manusia yang lebih cepat daripada pertambahan bahan makanan, manusia berkembang biak berdasarkan deret ukur, sedangkan bahan makanan berkembang menurut deret hitung. 4

Selain hal tersebut kurangnya SDM yang berkualitas sedangkan SDA yang berlimpah ruah hanya berupa sumber yang bersifat potensil saja. Perekonomian negara Indonesia adalah perekonomian agraris karena mayoritas masyrakatnya hanya menghasilkan hasil bumi dalam sektor pertanian, sedangkan keuntungannya tersebut tergantung kepada nai turunnya permintaan di pasar internasional (sesuai dolar).

Dalam segi mental masyarakatnya dapat dikatakan bahwa dalam segi pemerintahannya Indonesia masih bermental feodalistis sehingga melahirkan indivdu-individu yang memuji dan mengagungkan pemimpin dengan menjilat dan mencari muka, bukan dengan prestaikerja yang menjadi ukuran, tetapi sistemnya adalah siapa yang pandai menjilat maka ia akan duduk di kusi yang empuk, seingga pemerintah melupakan bagaimana seharusnya ia dapat mensejahterakan rakyatnya. Mentalita lainnya ialah karena hidup berorientasi kepaa barat, sehingga melahirkan suatu generasi yang konsumtif., bukan sebagi generasi yang kreatif dan dinamis. Mentalita lainnya adalah justru dalam kemiskinan yang meanda masyarakat biasanya terbiasa memboroskan apa yang ada padanya hanya demi gengsi sosial saja. Hal inilah yang dapat dijadikan sebagai landasan mengpa kemiskinan ini terus melanda Indonesia.

\section{Lembaga Dakwah}

Dakwah adalah "mengajak orang lain untuk meyakini dan mengamalkan aqidah dan syari'ah Islam yang terlebih dahulu telah diyakini dan diamalkan oleh pendakwah sendiri., tujuan dakwah yaitu membetangkan jalan Allah di atas bumi agar dapat dilalui ummat manusia"5. Hal ini dapat membuktikan bahwa kita sebagai mausia yang percaya kepada Allah Swt yang juga percay kepada Rasul-rasulnya harus mengetahui dengan jelas dan benar berjalan di jalan Allah Swt tersebut, bukan dengan meraba-raba, tetapi bukan pula dengan membabi buta, akan tetapi dengan satu keyakinan yang kuat yang timbul dari kesaaran yang kuat, dengan pengertian lain, bahwa kita sebagai seorang dai haruslah terlebih dahulu mendakwahkan diri kta

\footnotetext{
${ }^{4}$ Paul R. Ehlrich, Ledakan Penduduk, PT. Gramedia, Jakarta,1981, h. 51.

${ }^{5}$ Hasjmy, Dustur Dakwah Menurut Al-Qur'an, Bulan Bintang, Jakarta, 1944, h. 17
} 
sendiri baik dari segi perbuatan dan perkataannya dan tentu saja dalam ibadahnya.

Setelah mendakwahkan diri sendiri barulah kemudian mendakwahkan orang lain yaitu dengan menyeru atau mengajak orang lain, agar dapat meyakini dan mengamalkan ajaran Islam atau membentangkan jalan bagi ummat manusia agar dapat menjalankan semua perintah Allah Swt dan menjauhkan diri dari semua laranganlarangan-Nya.

Dakwah Islam terutama di Indonesia tampaknya akan berjalan dengan sangat sulit, ini dikarenakan masyarakat Indonesia mayoritas beragama Islam sehingga realitas yang ada menyatakan bahwa permasalahan yang ada di Indonesia sendiri akan menjadi lebih komplek dan meluas, dan juga hampir rata-rata masyarakat yang miskin di Indonesia adalah ummat Islam, sehingga tampaknya akan menambah kesulitan yang harus dihadapi oleh seorang dai.

Persoalan-persoalan masyarakat ini tentunya secara langsung dan tidak dapat mempengaruhi terciptanya beberapa tindakan yang kadang melanggar hukum dan mengganggu ketentraman orang banyak, bahkan karena masalah perut orang bisa melakukan perampokan, pencurian, penodongan dan sebagainya. Dengan demikian maka masalah kemiskinan yang berupa ketidakmampuan pemenuhan kebutuhan hidup sehari-hari bukanlah permasalahan yang sepele dan remeh karena mungkin ini dapat merubah diri seseorang yang mungkin tadinya baik berubah menjadi zolim.

Konsep dakwah secara luas adalah sebagaimana yang dikatakan Hasan Al-bana, bahwa dakwah sama pengertiannya dengan makna Islamiyyah: Dakwah kami adalah yang dapat melukiskan secara integral oleh kata "Islamiyyah", kata Islamiyyah ini memiliki makna yang sangat luas, tidak sebagaimana yang dipahami secara sempit oleh sebagaian orang. Kami yakin bahwa Islam adalah sistem nilai yang komperhensif, mencakup seluruh kehidupan. Ia memberi petunjuk bagi kehidupan manusia dalam semua aspeknya. Dan menggariskan formulasi sistematik yang akurat tentang hal itu, ia sanggup memberi solusi atas berbagai masalah ysng vital dan kebutuhan akan berbagai tatanan harkat kehidupan manusia. ${ }^{6}$

Melihat fenomena di atas, maka tentu saja diperlukan seorang dai yang handal yang tidak hanya berorientasi pada masalah keagamaan, akan tetapi juga permasalahan-permsalahan sosial lainnya seperti

\footnotetext{
${ }^{6}$ Noorchozin Sufri, “ Dakwah Dalam Masyarakat Informasi Global (Tantangan dan
} Peluang)", Mufida, Vol. 1, 1999, h. 4. 
masalah kemiskinan ini, karena sorang dai juga harus dapt peka dan mampu membaca situasi riil yang terjadi di masyarakat dan tentunya diharapkan juga dapat menemukan jalan keluarnya sehingga masyarakat memiliki pegangan dan tuntunan dn masyarakt tidak menjadi bingung, kacau dan jauh dari tuntunan agama. Dikarenakan permasalahan dakwah itu begitu komplek maka dibutuhkan suatu lembaga dakwah yang terorganisir dan sistematis dalam rangka dakwah efektif sehingga akan memudahkannya dalam menemkan jalan keluar yang baik dalam permasalahan-permasalahan tersebut. Dalamsalah satu firman Allah Quran surat al-Mauun ayat 1-3 yang terjemahannya:

Artinya: tahukah kamu orang yang mendustakan agama? Itulah orang yang menghardik anak yatim dan idak menganjurkan memberi makan orang miskin (QS.107: 1-3)

Dalam ayat ini bahwa kemiskinan adalah tanggung jawab setiap manusia baik secara individu maupun secara melembaga maka bila tidak demikian maka ia termasuk orang-orang yang mendustakan agama, karena kita menganjurkan memberi makan orang miskin adalah sama artinya dengan mengentaskan kemiskinan baik secara lisan (dakwah) maupun secara perbuatan.

Adapun peran lembaga dakwah ini adalah untuk mempengaruhi masyarakat agar menjadi tertarik perhatiannya dan kemudian mempunyai pengalaman-pengalaman yang berhasil di dalam pemecahan masalah mereka tersebut. Akan tetapi tetap harus melalui usaha-usaha mereka juga dikarenakan perubahan hidup mereka tentunya harus ada keinginan dari diri mereka sendiri.

\section{E. Pengentasan Kemiskinan}

Pada dasarnya kemiskinan adalah suatu permasalahan ummat yang sulit di- entaskan, karena kemiskinan ini memiliki banyak sekali keterkaitan dengan berbagai macam faktor penyeebab nya. Akan tetapi akan terdapat 3 hal yang dapat dijadikan sebagai cara pengentasan kemikinan:

1. Kewajiban individu

2. Kewajiban orang lain (individu dan lembaga)

3. Kewajiban pemerintah. ${ }^{7}$

1. Kewajiban individu

${ }^{7}$ Qurish Shihab, Wawasan Alqur'an, Mizan Media Utama, Bandung,2003, h. 453. 
Kewajiban individu ini adalah kewajiban dari setiap individu masyarakat dalam rangka merubah nasibnya tersebut, yang tentunya dengan berusaha dan berkerja yang merupakan dasar utama dalam memperoleh kecukupan hidup. Hal ini sesuai dengan firman Allah Swt

Artinya: apabila telah selesai sholat (jumat) maka bertaburanlah di muka bumi dan carilah fahl (kelebihan) dari Allah Swt (QS. 62:10)

Firman Allah ini sangatlah jelas, bahwa ketika manusia selesai beribadah yang merupakan refleki keimanan seseorang, maka hendaknya ia lagsung melaksanakan kewajibannya di muka bumi, yaitu mencari rizki yang telah Allah sediakan di bumi.

Dengan demikianmenyiratkan bahwa Islam telah mewajibkan kepada ummat manusia untuk hidup dalam kemiskinan, arena Allah Swt telah memberikan nikmat yang banyak berupa harapan bumi serta isinya yang tidak akan habis-habisnya. Dengan demikian sebenarnya kemiskinan itu dibuat oleh manusia nya itu terdiri, karena tidak adaya sebuah kesadaran yang tinggi akan pentingnya mencari nafkah.

2. Kewajiban orang lain (Individu dan Lembaga)

Kewajiban orang lain ini pada dasarnya dapat bersifat individu maupun melembaga, akan tetapi yang perludiingat bahwa bila menggantungkan pengentasan kemiskinan dengan melakukan sumbangan-sumbangan yang bersifat sukarela dan diberikan kepada masyarakat miskin secara cuma-cuma itu tidak dapat diandalkan lagi, teori ini bukankah telah sering di praktekan seabad-abad lamanya, namun hasilnya tidak pernah memuaskan, akan dapat menyebakan masyarakat malas dan hanya dapat berpangku tangan menunggu kucuran dana tersebut tanpa berbuat apa-apa dengan dana yang diberikan tersebut.

Lain halnya bila dilakukan oleh sebuah lembaga, dengan lembaga tersebut dana yang dikumpulkan tersebut dapat dimanfaatkan dengan mengadakan pelatihan-pelatihan langsung kepada masyarakat atau melakukan pembinaan-pembinaan kepada mereka dalam bentuk keterampilan-keterampilan, sehingga mereka memiliki pegangan utuk mencari nafah tersebut, dan ini tampaknya merupakan solusi baik untuk pengentasan-pengentasan kemiskinan tersebut, selain tetap melakukan dakwah-dakwah Islam.

3. Kewajiban Pemerintah

Pemerintah memiliki kewajiban yang besar dalam pengentasan kemiskinan, yaitu dengan mencukupi setiap kebutuhan warga negara, melalui sumber-sumber dana yang sah dan juga terus melakukan perhatian yang tinggi kepada masyarakat ekonomi lemah atau miskin 
ini dengan memprioritaskannya, bukan mereka yang sudah kaya dan mapan.

Pada dasarnya adalah pemerintah wajib memberikan kebijakankebijakan yang bersifat adil yang sesuai dengan masyarakat, keadilan yag dimaksudkan disini adalah sesuai dengan kebutuhan setiap individu masyarakat, sehingga tidak akan teru terjadi ketimpangan yang semakin menonjol.

Ada beberapa metode pendekatan kepada masyarakat miskin dalam rangka pembinaan kepada mereka dengan maksud agar lembaga dakwah tersebut dapat diterima oleh mereka, sehingga mereka merasa bahwa lembaga dakwah tersebut memang benar-benar ingn membantu mereka, dan juga diharapkan nantinya dapat mempermudah lembaga dakwah dalam rangka melakukan pengentasan kemiskinan tersebut.

\section{F. Metode-Metode Lembaga Dakwah}

Satu hal yang diperlukan oleh lembaga dakwah adalah pertamatama dalam pemberdayaan masyarakat miskin tentulah mereka harus mengetahui pertama-tama menentukn dahulu daerah yang hendak jadi sasaran yang tentunya terdapat orang yang hendak dibina tersebut. Kedua mengetahui metode apa yang tepat digunakan, ketiga mengetahui kapan mempergunakannya, terakhir mengetahui keefektifannya.

Adapun metode-metode yang dilakukan antara lain:

1. Direct Contact

"yaitu mengadakan kontak langsung (face to face) baik secara individual maupun secara kelompok". 8

Agar metode ini dapat dilakukan efektif, adalah:

a. Menyenangkan dalam berdiskusi dan bergaul dan terangkan bahwa kehadiran para dai ini adalah untuk menolong mereka dari kesulitan yang mereka hadapi.

b. Mendengarkan dengan baik semua keluh kesah mereka.

c. Hilangkan argumentasi yang bersifat memojokkan

d. Bila ide-ide baru dan penting keluar daripercakapan buatlah suasana sedemikian rupa sehingga masyarakat merasa diikutsertakan. Dan terus meyakini masyarakat agar mereka memiliki tanggung jawab dalam pelaksanaannya

e. Terus mengupayakan program-program yang direncanakan dan dilaksanakan tersebut

f. Bila meninggalkan mereka hendaknyalah tinggalkan kesan yang baik sehingga mereka akan terus melaksanakan semua program

${ }^{8}$ Surjadi, Op.Cit., h. 86 
yang dilaksanakan tersebut dan berharap agar mereka cepat kembali lagi.

2. Demonstrasi Hasil

Biasanya masyarakat miskin selalu menggunakan cara-cara yang bersifat tradisionil atau sudah kuno dalam mencari nafkah atau cara berfikirnya, maka seorang dai harus dapat meyakini mereka untuk merubah sistem mereka yang kuno tersbut kepada sesuatu yang baru dengan cara mendemonstrasikannya.

Adapun cara yang tepat dalam mensosialisasikannya ide-ide baru tersebut, diantaranya dengan cara-cara sebagai berikut:

a. Jelaskan bahwa praktek baru yang didemonstrasikan tersebut dapat mereka lakukan.

b. Pastikan kepada masyarakat bahwa masalah-masalah pokok mereka dapat dipecahkan dengan bantuan demonstrai tersebut.

c. Pastikan bahwa dai yang mendemonstrasikan tersebut memang telah ahli, sehingga mereka dapat menjelaskan dan mampu dalam membimbing penduduknya nanti

d. Pastikan dai dapat mengawasnya dalam setiap langkah pelaksanaannya.

e. Membandingkan dua cara yang pertama yang berifat baru (yang didemonstrasikan tersebut) dan yang satunya lagi adalah caracaramereka sebelumnya, sehingga dapat membandingkan keduaya dan masyarakat tersebutpun menjadi percaya.

3. Demonstrasi metode (Proses)

Yaitu memperlihatkan kepada orang lain bagaimana memperkembangkan sesuatu yang ada yang hendak dilakukan atau bagaimana prosesnya.

Demonstrasi proses ini menuntut dai agar berprofesi unik, sebagai guru menjelaskan an melatih orang-orang bagaimana mengerjakan sesuatu, pada mula pertama demonstrasi ini dapat dipergunakan untuk menarik perhatian orang-orang. Bila perhatiannya telah tertarik maka proses mengajar dan melatihpun akan menyusul.

Agar metode ini dapat efektif, maka dapat dilakukan hal-hal sebagai berikut

a. Hadirin diusahakan sebanyak mungki hadir, hal ini diperlukan karena demonstrasi proses ini efektif hanya bila orang-orang melihat,mendengar, mengerti dan merasa endiri belajar mengerti apa yang didemonstrasikan

b. Menjelaskan apa yang didemonstrasikan tersebut sejak dari mulainya. Dan megapa demonstrasi tersebut dilaksanakan. 
c. Mengusahakan agar masyarakat berani melaksanakan apa yang di demonstrasikan tersebut dan jangan terlalu memberi bantuan terus menerus biarkan mereka menjalankan dengan sendirinya.

Beberapa metode-metode ini dapat dikatakan sebagai teorinya saja, akan tetapi prakteknya tetap harus diserahkan kepada lembaga dakwahnya itu sendiri, adapun pelaksanaanya tetap harus dilaksanakan secara tuntas dan bertanggung jawab untuk ;

a. Memantau perjalanan dakwah

b. Menganalisis roses dakwah

c. Meneliti medan dakwah

d. Merencanakan program dakwah yang tepat sasaran

e. Mengevaluasi efek atau hasil dakwah. ${ }^{9}$

Dengan demikian dalam pengentasan kemiskinan tersebut, lembaga dakwah tidak boleh bersifat asal-asalan, akan tetapi harus dilaksanakan secara bertanggung jawab dan diketahui hasilnya.

\section{G. Kesimpulan}

Dari beberapa uraian diatas, maka diambil kesimpulan sebagai berikut:

1. Kemiskinan merupakan suatu keadaan ketidakmampuan pemenuhan kebutuhan hidup sehari-hari.

2. Faktor penyebab kemiskinan tersebut sangatlah banyak akan tetapi yang paling dominan adalah kurangnya kesadaran dalam diri manusia itu sendiri untuk merubah kehidupannya ke arah yang lebih baik lagi atau karena kemalasannya.

3. Penanggulangan kemiskinan dapat dilakukan melalui 3 faktor yaitu kewajiban individu sendiri, kewajiban orang lain baik individu maupun lembaga dan terakhir kewajiban pemerintah dalam pelaksanaan kebijakan-kebijakannya.

4. Dakwah tidak hanya mengajak, menyeru dan memanggil orang lain untuk ke jalan Allah Swt, ini adalah pengertian yang sempit adapun dakwah itu harus menghadapi permasalahan-permasalahan yang riil yang ada di tengah-tengah masyarakat, dan tentu persoalanpersoalan yang bersifat global, diantaranya adalah masah kemiskinan.

5. Dalam melaksanakan tugasnya yang paling pokok adalah dengan melakukan terjun langsung dalam masyarakat miskin dan meakukan pemberdayaan mereka, dengan memberikan motivasi, solusi berupa keterampilan-keterampilan dan lain sebagainya, dalam merubah kehidupan mereka agar lebih baik.

\footnotetext{
${ }^{9}$ Noorchozin Supri, Op. Cit., h. 5.
} 
6. Lembaga dakwah dituntut tanggung jawabnya sampai tuntas, atau bila melakukan pemberdayaan terhadap masyarakat harus sampai terlihat hasilnya.

\section{DAFTAR PUSTAKA}

Adi Sasono, Zakat Untuk Mengurangi Kemiskinan Ummat, Makalah. 1955.

Hasjmy, Dustur Dakwah Menurut Al-Qur'an, Bulan Bintang, Jakarta, 1944.

Nabil Subhi Ath-Thawil, Kemiskinan dan Keterbelakangan Negara-Negara Muslim, Mizan, Bandun, 1991.

Noorchozin Sufri, " Dakwah Dalam Masyarakat Informasi Global (Tantangan dan Peluang)", Mufida, Vol. 1, 1999.

Qurish Shihab, Wawasan Alqur'an, Mizan Media Utama, Bandung,2003.

Paul R. Ehlrich, Ledakan Penduduk, PT. Gramedia, Jakarta, 1991.

Surjadi, Dakwah Islam dan Pembangunan Masyarakat Desa, Mandar Maju, Bandung, 1989.

W.J.S. Poerdarminta, Kamus Umum Bahasa Indonesia, Balai Pustaka, Jakarta, 1986. 